\title{
Biopestisida Organik Berbahan Aktif Bacillus subtilis dan Pseudomonas fluorescens untuk Mengendalikan Penyakit Layu Fusarium pada Anyelir
}

\author{
Hanudin, W. Nuryani, E. Silvia Yusuf, dan B. Marwoto \\ Balai Penelitian Tanaman Hias, Jl. Raya Ciherang-Pacet, Cianjur 43253 \\ Naskah diterima tanggal 11 Januari 2011 dan disetujui untuk diterbitkan tanggal 27 Juni 2011
}

\begin{abstract}
ABSTRAK. Anyelir (Dianthus caryophillus L.) merupakan salah satu jenis tanaman hias yang mempunyai nilai ekonomi tinggi. Penyakit utama yang menyerang tanaman ini ialah layu Fusarium yang disebabkan oleh Fusarium oxysporum f. sp. dianthi dapat menurunkan kualitas dan kuantitas produksi tanaman sekitar 20-60\%. Pengendalian yang selama ini dilakukan oleh petani bertumpu pada penggunaan pestisida kimia sintetik. Namun penggunaan bahan kimia tersebut tidak mampu mengeradikasi patogen secara sempurna, terutama pada lapisan tanah yang agak dalam. Salah satu cara pengendalian berwawasan lingkungan ialah menggunakan musuh alami. Penelitian ini dilaksanakan di Laboratorium dan Rumah Kaca Balai Penelitian Tanaman Hias (1.100 m dpl.), sejak Mei sampai Desember 2009. Penelitian bertujuan mengetahui pengaruh Bacillus subtilis dan Pseudomonas fluorescens yang diformulasi dalam bentuk biopestisida organik cair dalam pengendalian layu Fusarium pada tanaman anyelir. Rancangan yang digunakan ialah acak kelompok dengan 10 perlakuan, yaitu 10\% ekstrak kascing $+10 \%$ molase + B. subtilils $+P$. fluarescens (BP) dan 10\% ekstrak pupuk kandang kuda $+10 \%$ molase + BP masing-masing konsentrasi 0,1, 0,3, 0,5 , dan $0,7 \%$, dazomet $0,2 \%$, serta kontrol (air ledeng), dengan empat ulangan. Hasil penelitian menunjukkan bahwa populasi bakteri antagonis setelah dilakukan proses fermentasi selama 3 minggu, meningkat dibandingkan sebelum fermentasi. Rerata populasi awal sebelum fermentasi bakteri antagonis $10^{7}-10^{9} \mathrm{cfu} / \mathrm{ml}$ meningkat menjadi $10^{10}-10^{12} \mathrm{cfu} / \mathrm{ml}$ pada 3 minggu setelah fermentasi. Populasi kedua agens biokontrol tersebut setelah penyimpanan selama 2 bulan cenderung stabil berkisar antara $10^{10}-10^{11} \mathrm{cfu} / \mathrm{ml}$. Perlakuan B. subtilis dan P. fluorescens yang disuspensikan ke dalam ekstrak kascing + molase pada taraf konsentrasi 0,5\% kemudian difermentasikan dalam biofermentor selama 3 minggu secara konsisten dapat menekan serangan F. oxysporum $\mathrm{f}$. sp. dianthi pada anyelir. Implikasi hasil penelitian ini dapat meningkatkan daya saing komoditas tanaman hias melalui pemanfaatan sumber daya alam nasional secara optimal berkelanjutan untuk mendukung industri tanaman hias yang berdaya saing tinggi.
\end{abstract}

Katakunci: Dianthus caryophillus; Biopestisida organik; Bacillus subtilis; Pseudomonas fluorescens; Pengendalian; Fusarium oxysporum f. sp. dianthi

\begin{abstract}
Hanudin, W. Nuryani, E. Silvia Yusuf, and B. Marwoto. 2011. A Study of Organic Biopesticide Containing Bacillus subtilis and Pseudomonas fluorescens for Controling Fusarium Wilt on Carnation. Carnation (Dianthus caryophillus L.) is one of the most economically important cut flowers in Indonesia. The crops is commonly cultivated in the highland areas of the country. Cultivations of the crops in the production center areas have faced various problems, especially wilt disease caused by Fusarium oxysporum f. sp. dianthi as the most important one. Based on the field observation it is known that the disease could reduce plant production and its yield quality up to $20-60 \%$. To control the disease, farmers usually use a synthetic chemical pesticides. However the control measures are not sufficiently effective to overcome the diseases problems. Therefore, an alternative control measures which are more environmentally friendly is necessary. The use of biocontrol agents is nowdays bring popular to be recommended to control the disease. A study on the control of fusarial wilt disease on carnation was carried out in the Laboratory and Glasshouse of Indonesian Ornamental Crops Research Institute (1,100 m asl.) from May to December 2009, using Bacillus subtilis and Pseudomonas fluorescens formulated in the liquid organic pesticide. The study was arranged in a randomized block design, with 10 treatments i.e. $10 \%$ vermi compost $+10 \%$ molase $+\mathrm{BP}$ and $10 \%$ horse manure $+10 \%$ molase + BP consentration $0.1,0.3,0.5,0.7 \%$ resfectively, dazomet $0,2 \%$ and control with four replications. The results showed that population of antagonistic bacterial was increased from $10^{7}-10^{9}$ to $10^{10}-10^{12} \mathrm{cfu} / \mathrm{ml}$ after 3 weeks fermentation in the organic carrier. The population of two antagonistic bacteria was likely stable on $10^{10}-10^{11}$ $\mathrm{cfu} / \mathrm{ml}$ after storing 2 months. The treatments of $B$. subtilis and $P$. fluorescens suspended in the vermi compost extract and molases on the concentration level of $0.5 \%$ and formulated in the biofermentor for 3 weeks were consistenly effective in reducing Fusarium wilt on carnation. The implication of research results could be increase commodity competitive ability of ornamental plants by using national nature resource on a continuity for support the ornamental plants industry with high competitiveness.
\end{abstract}

Keywords: Dianthus caryophillus; Organic biopesticide, Bacillus subtilis; Pseudomonas fluorescens; Controlling; Fusarium oxysporum f. sp. dianthi

Anyelir(Dianthus caryophillus L.) merupakan salah satu jenis tanaman hias yang mempunyai nilai ekonomis tinggi. Penyakit utama yang menyerang tanaman ini ialah layu Fusarium 
yang disebabkan oleh Fusarium oxysporum f. sp. dianthi. Patogen ini dapat menurunkan kualitas dan kuantitas produksi tanaman sekitar 20-60\% (Manulis et al. 1994).

Beberapa upaya pengendalian penyakit layu pada anyelir telah banyak dilaporkan. Pengendalian yang dilakukan oleh petani mengandalkan penggunaan pestisida kimia sintetik (Maryam dan Djatnika 1994). Di luar negeri pengendalian layu Fusarium dilakukan dengan fumigasi tanah menggunakan metil bromida $(800 \mathrm{~kg} / \mathrm{ha})$. Namun perlakuan fumigasi tersebut tidak mampu mengeradikasi patogen penyebab layu secara sempurna, terutama pada lapisan tanah yang agak dalam (Yephet et al. 1996). Oleh karena itu cara-cara pengendalian alternatif yang lebih sesuai dengan falsafah pengendalian penyakit tanaman yang ramah lingkungan perlu diperhatikan (de Bach 1974). Salah satu cara pengendalian berwawasan lingkungan ialah melaksanakan program pertanian organik.

Pertanian organik adalah sistem manajemen produksi terpadu yang menghindari penggunaan pupuk buatan, pestisida kimia sintentik, dan hasil rekayasa genetik. Penerapan pertanian organik dimaksudkan untuk menekan pencemaran udara, tanah, air, dan lingkungan hidup (Isroi 2005). Alasan kesehatan dan kelestarian lingkungan hidup menjadikan pertanian organik sebagai salah satu alternatif pertanian modern. Pertanian organik mengandalkan penggunaan bahan-bahan alami untuk menggantikan bahan kimia sintetik. Namun, petani sering mengeluh bahwa produktivitas hasil pertanian organik yang diterapkan cenderung rendah dan lebih rentan terhadap serangan hama dan penyakit. Masalah ini dapat diatasi dengan memanfaatkan produk mikrobe yang diambil dari sumber-sumber kekayaan hayati di dalam negeri.

Bacillus subtilis dan Pseudomonas fluorescens merupakan mikrobe antagonis yang sangat potensial untuk dikembangkan sebagai agens pengendali patogen pada tanaman anyelir. Pada penelitian ini kedua bakteri antagonis tersebut dicampurkan dalam satu media bahan pembawa organik (ekstrak kascing dan molase), dengan harapan dapat meningkatkan kemangkusannya dalam menekan F. oxysporum f. sp. dianthi pada anyelir. Kedua bakteri tersebut bersifat kompatibel satu sama lain dan diformulasi dalam bentuk biopestisida semi-organik dengan nama dagang Prima BAPF, dievaluasi kemangkusannya, dan dipatenkan oleh Kementerian Hukum dan Hak Azasi Manusia Republik Indonesia melalui Direktorat Jenderal Hak Kekayaan Intelektual (Dirjen Haki) dengan nomor sertifikat paten ID. 0 022 384, 12 Januari 2009 (Hanudin et al. 2009).

Prima BAPF mengandung bahan aktif berupa B. subtilis nomor isolat BHN 4 dan P. fluorescens nomor isolat Pf 18 , sedang bahan pembawanya ialah larutan $0,1 \mathrm{M} \mathrm{MgSO}_{4}$ $7 \mathrm{H}_{2} \mathrm{O}$ yang ditambah $1 \%$ monosodium glutamat dan minyak sawit yang ditambah parafin hidrokarbon dengan perbandingan antara bahan aktif dan pembawa 1:4:5 (v/v) serta kerapatan bakteri bahan aktif dalam formulasi $10^{9} \mathrm{cfu} /$ ml. Pada penelitian ini komposisi Prima BAPF tersebut disempurnakan pada penggunaan jenis bahan aktif maupun bahan pembawanya. Hal ini dilakukan karena efektivitas biopestisida Prima BAPF terhadap patogen sasaran tidak stabil, oleh karena itu perlu disempurnakan. Penyempurnaan tersebut dilakukan terhadap bahan aktif yang semula menggunakan $B$. subtilis nomor isolat BHN 4 dan P. fluorescens nomor isolat Pf 18, sedang pada formulasi ini menggunakan $B$. subtilis nomor isolat Bs 12 dan P. fluorescens nomor isolat $\mathrm{Pf} 2$. Adapun bahan pembawa yang disempurnakan memodifikasi metode Suryana dan Cahyono (2008) dalam pembuatan pupuk organik cair yang diberi nama dagang Biovermi.

Penelitian bertujuan mendapatkan informasi viabilitas bahan aktif biopestisida (B. subtilis dan P. fluorescens) dalam bahan pembawa berupa ekstrak bahan organik (kascing atau pupuk kandang kotoran kuda ditambah molase). Di samping itu untuk memperoleh konsentrasi dan prototipe formulasi biopestisida organik berbahan aktif $B$. subtilis dan P. fluorescens yang efektif mengendalikan penyakit layu Fusarium pada anyelir.

Hipotesis yang diajukan pada percobaan ini ialah bahwa B. subtilis dan P. fluorescens diduga dapat hidup dalam ekstrak kascing dan kotoran kuda yang difermentasikan. Prototipe formulasi B. subtilis dan P. fluorescens yang disuspensikan ke dalam ekstrak kascing yang difermentasikan dapat mengendalikan $F$. oxysporum f. sp. dianthi pada tanaman anyelir. 


\section{BAHAN DAN METODE}

Penelitian dilakukan di Laboratorium dan Rumah Kaca Balai Penelitian Tanaman Hias ( $1.100 \mathrm{~m}$ dpl.) Segunung, pada bulan Mei sampai Desember 2009. Ruang lingkup penelitian ini sebagai berikut:

\section{Pembuatan Propagul Bahan Aktif Biopestisida Organik}

Propagul bahan aktif biopestisida ini ialah biakan murni B. subtilis nomor isolat Bs 12 ditumbuhkan pada media nutrien agar, sedang $P$. fluorescens nomor isolat Pf 2 ditumbuhkan pada media King's B yang mengandung $0,01 \mathrm{M} \mathrm{FeCl}_{3}$. Kemudian biakan murni tersebut dieramkan di dalam inkubator pada suhu $30 \pm 2^{\circ} \mathrm{C}$ selama 24 jam. Isolat bakteri tersebut diambil 3 loop penuh dan disuspensikan ke dalam $10 \mathrm{ml}$ air steril, divorteks agar homogen sehingga terbentuk suspensi dengan kerapatan $10^{12} \mathrm{cfu} / \mathrm{ml}$. Suspensi isolat tersebut sebanyak $1 \mathrm{ml}$ dituangkan ke dalam $500 \mathrm{ml}$ media nutrient broth (NB) di dalam erlenmeyer berkapasitas $750 \mathrm{ml}$, kemudian dimasukkan ke dalam penangas air pada suhu $30^{\circ} \mathrm{C}$ sambil digoyang di dalam shaker pada kecepatan 3 rpm selama 24 jam. Sel bakteri dipanen dengan cara mengambil tiap isolat lalu disuspensikan ke dalam akuades steril. Sebanyak 10\% dari larutan propagul tersebut kemudian dimasukkan ke dalam media perbanyakan massal sebagai perlakuan.

\section{Media Perbanyakan Massal Bahan Pembawa Biopestisida Organik}

Pembuatan media perbanyakan massal mengikuti metode Suryana dan Cahyono (2008) yang dimodifikasi dalam pembuatan pupuk organik cair yang diberi nama dagang Biovermi. Pada pembuatan Biovermi menggunakan bahan aktif berupa mikrobe yang berfungsi sebagai penambat N, pelarut fosfat, dan penghasil hormon tumbuh seperti Azotobacter sp., Azospirillum sp., dan Aspergillus sp. serta gula merah, dan ekstrak kascing sebagai bahan pembawa. Pada percobaan ini pembuatan pupuk organik cair dimodifikasi menggunakan B. subtilis dan P. fluorescens sebagai bahan aktif dan molase pengganti gula merah sebagai bahan pembawa. Prosedur pembuatan media perbanyakan massal ialah sebagai berikut: $1 \mathrm{~kg}$ kascing atau pupuk kandang kuda yang matang, masukkan ke dalam 91 air, lalu direbus pada suhu $100^{\circ} \mathrm{C}$ selama 30 menit. Selanjutnya larutan disaring dengan kain kassa berukuran 200 mesh, air hasil saringan difermentasikan selama 3 minggu di dalam biofermentor sebagai media basal yang dicampur dengan molase $10 \%$.

\section{Uji Viabilitas Bahan Aktif dalam Bahan Pembawa Biopestisida}

Viabilitas bahan aktif dalam bahan pembawa merupakan tolok ukur masa kadaluarsa biopestisida tersebut. Apabila viabilitas bahan aktif semakin lama, maka masa kadaluarsa biopestisida tersebut semakin panjang. Adapun cara pengujian dilakukan melalui pengenceran berseri menggunakan metode Hsu et al. (1994) yang dimodifikasi.

Biopestisida ini disimpan pada suhu ruang $\left(25 \pm 2^{\circ} \mathrm{C}\right)$ dan viabilitas bahan aktif diamati setiap bulan, mulai 0-2 bulan setelah penyimpanan. Percobaan menggunakan rancangan acak lengkap, yang terdiri atas empat perlakuan dengan enam ulangan. Uraian tiap perlakuan tersebut disajikan pada Tabel 1.

Formulasi dan Konsentrasi Biopestisida Organik terhadap Waktu Inkubasi, Penyakit Layu Fusarium, AUDPC, Diskolorisasi Floem, dan Persentase Penekanannya

Formulasi dan konsentrasi biopestisida terhadap waktu inkubasi, dan intensitas serangan $F$. oxysporum f. sp. dianthi pada anyelir

Bibit tanaman anyelir varietas lokal Cihideung yang rentan terhadap layu Fusarium, yang berumur

\begin{tabular}{cc} 
Tabel 1. & $\begin{array}{c}\text { Jumlah perlakuan uji viabilitas } \\
\text { bahan aktif dalam bahan pembawa } \\
\text { biopestisida (Number of treatments } \\
\text { on viability test against active and } \\
\text { carrier ingredient of biopesticide) }\end{array}$ \\
\hline $\begin{array}{c}\text { Kode perlakuan } \\
\text { (Treatments } \\
\text { code) }\end{array}$ & $\begin{array}{c}\text { Komposisi formulasi } \\
\text { biopestisida } \\
\text { (Composition of biopesticide } \\
\text { formulations) }\end{array}$ \\
\hline $\mathrm{A}$ & $10 \% \mathrm{Kas}+10 \% \mathrm{Mol}$ \\
$\mathrm{B}$ & $10 \% \mathrm{Pkd}+10 \% \mathrm{Mol}$ \\
$\mathrm{C}$ & $10 \% \mathrm{Kas}+10 \% \mathrm{Mol}+\mathrm{BP}$ \\
$\mathrm{D}$ & $10 \% \mathrm{Pkd}+10 \% \mathrm{Mol}+\mathrm{BP}$ \\
\hline
\end{tabular}

Keterangan (Remarks) :

Kas $=10 \%$ kascing $($ Vermi compost $)$

$\mathrm{Pkd}=10 \%$ Ppk kandang kotoran kuda (Horse manure) $\mathrm{BP}=$ B. subtilis + P. fluorescens

$\mathrm{Mol}=10 \%$ molase 
21 hari setelah stek pucuk (HSSP) diperoleh dari penangkar bibit di Sarongge, Pacet, Cianjur. Bibit ditanam dalam polibag berdiameter $20 \mathrm{~cm}$ yang berisi campuran tanah dan pupuk kandang $1: 1 \mathrm{v} / \mathrm{v}$ yang disterilkan, yang sebelumnya telah diinokulasi F. oxysporum berdasarkan metode Straathof et al. (1993), Loffler dan Rumine (1991).

Biakan murni $F$. oxysporum f. sp. dianthi ditumbuhkan pada media potato dextrose agar (PDA), kemudian pada umur 7 hari selelah investasi, biakan $F$. oxysporum f. sp. dianthi dipanen. Satu cawan petri yang berisi biakan $F$. oxysporum $\mathrm{f}$. sp. dianthi dengan konsentrasi $10^{7} \mathrm{sel}$ spora $/ \mathrm{ml}$ diinfestasikan ke dalam media campuran oatmel: tanah $(1: 5 \mathrm{v} / \mathrm{v})$ yang disterilkan dengan autoclave (suhu $120^{\circ} \mathrm{C}$, selama 15 menit), kemudian media diinkubasikan dalam ruangan gelap selama 3

Tabel 2. Jumlah perlakuan dalam percobaan kemangkusan biopestisida terhadap intensitas serangan $F$. oxysporum pada anyelir di rumah kaca (Number of treatments on biopesticide effectiveness to $F$. oxysporum on carnation at glasshouse)

\begin{tabular}{|c|c|}
\hline \multicolumn{2}{|c|}{ Perlakuan (Treatments) } \\
\hline $\begin{array}{l}\text { Kode lapangan } \\
\text { (Field code) }\end{array}$ & Nama jenis (Type) \\
\hline $\mathrm{A} 1$ & $\begin{array}{l}10 \% \text { Kas }+10 \% \text { Mol }+ \text { BP, Kons } \\
0,1 \% *\end{array}$ \\
\hline A2 & $\begin{array}{l}10 \% \text { Kas }+10 \% \text { Mol }+ \text { BP, Kons } \\
0,3 \%\end{array}$ \\
\hline A3 & $\begin{array}{l}10 \% \text { Kas }+10 \% \text { Mol }+ \text { BP, Kons } \\
0,5 \%\end{array}$ \\
\hline A4 & $\begin{array}{l}10 \% \text { Kas }+10 \% \text { Mol }+ \text { BP, Kons } \\
0,7 \%\end{array}$ \\
\hline A5 & $\begin{array}{l}10 \% \mathrm{Pkd}+10 \% \mathrm{Mol}+\mathrm{BP}, \text { Kons } \\
0,1 \%\end{array}$ \\
\hline A6 & $\begin{array}{l}10 \% \mathrm{Pkd}+10 \% \mathrm{Mol}+\mathrm{BP}, \text { Kons } \\
0,3 \%\end{array}$ \\
\hline A7 & $\begin{array}{l}10 \% \text { Pkd }+10 \% \text { Mol }+ \text { BP, Kons } \\
0,5 \%\end{array}$ \\
\hline A8 & $\begin{array}{l}10 \% \mathrm{Pkd}+10 \% \text { Mol, }+ \text { BP, Kons } \\
0,7 \%\end{array}$ \\
\hline A9 & Dazomet $0,2 \%$ \\
\hline A10 & Kontrol (Air ledeng) \\
\hline
\end{tabular}

\section{Keterangan (Remarks):}

Kas $=$ Kascing (Vermi compost)

$\mathrm{Mol}=$ Molase $($ Molases $)$

$\mathrm{Pkd}=$ Pupuk kandang kuda (Horse manure)

$\mathrm{BP}=B$. subtilis $+P$. fuorescens

Konsentrasi formulasi biopestisida yang digunakan mulai 0,1 sampai dengan $0,7 \%$ minggu pada suhu ruangan $\left(25 \pm 2^{\circ} \mathrm{C}\right)$. Setelah inokulum tumbuh memenuhi media, selanjutnya media dicampur tanah dengan perbandingan 1 : $100 \mathrm{v} / \mathrm{v}$, kemudian campuran tersebut digunakan untuk media pertumbuhan tanaman anyelir. Jumlah propagul yang terdiri atas mikro, makro konidia, dan klamidiospora yang digunakan dalam campuran media tersebut ialah $\pm 10^{5}-1,5 \times 10^{5}$ propagul $/ \mathrm{g}$ tanah yang dihitung berdasarkan pengenceran berseri mengadopsi metode Komada (1975) serta metode Loffler dan Mouris (1989).

Aplikasi biopestisida berbahan aktif $B$. subtilis dan P. fluorescens dilakukan sejak saat tanam, dengan interval 7 hari. Metode aplikasi ialah sebagai berikut: akar tanaman anyelir direndam dalam suspensi biopestisida selama 10 menit, kemudian diikuti dengan penyemprotan pada media tanam dan jaringan tanaman. Konsentrasi yang digunakan untuk kedua mikrobe antagonis tersebut ialah $0,1,0,3,0,5$, dan $0,7 \%$ dengan kerapatan $10^{10} \mathrm{cfu} / \mathrm{ml}$.

Populasi tanaman yang digunakan pada percobaan ini ialah 10 tanaman/perlakuan/ulangan, sehingga total tanaman yang diperlukan 400 tanaman. Rancangan yang digunakan ialah acak kelompok dengan 10 perlakuan dan empat ulangan. Perlakuan terdiri atas empat taraf konsentrasi biopestisida $0,1,0,3,0,5$, dan $0,7 \%$, satu fungisida kimiawi sintetik sebagai kontrol positif (dazomet konsentrasi 0,2\%), dan kontrol (air ledeng), sehingga total 10 perlakuan (Tabel 2).

Peubah yang diamati meliputi waktu inkubasi (WI) dan intensitas penyakit layu. Waktu inkubasi diamati setiap hari sampai 35 hari setelah tanam (HST). Intensitas penyakit diamati berdasarkan metode Yephet et al. (1996) setiap 14 hari sampai tanaman berbunga pertama.

\section{Luas Areal di bawah Kurva Perkembangan Penyakit $F$. oxysporum f. sp. dianthi}

Luas areal di bawah kurva perkembangan penyakit (AUDPC) pada percobaan ini mencerminkan kemangkusan suatu perlakuan dalam menekan patogen. Semakin rendah angka AUDPC semakin efektif perlakuan tersebut mengendalikan patogen. AUDPC dihitung menggunakan integrasi trapezoidal dengan rumus (Jeger dan Viljanen-Rollinson 2001) 


$$
\operatorname{AUDPC}=\sum_{\mathrm{i}}^{\mathrm{n}-1}\left|\frac{\left(\mathrm{Y}_{\mathrm{i}+1}+\mathrm{Y}_{\mathrm{i}}\right)}{2}\right|\left(\mathrm{t}_{\mathrm{i}+1}-\mathrm{t}_{\mathrm{i}}\right)
$$

di mana:

$$
\begin{array}{ll}
\mathrm{Y} \mathrm{i}+1 & =\text { Data pengamatan } \mathrm{ke}-\mathrm{i}+1, \\
\mathrm{Y} \mathrm{i} & =\text { Data pengamatan ke- } \mathrm{i}, \\
\mathrm{ti}+1 & =\text { Waktu pengamatan ke- } \mathrm{i}+1, \\
\mathrm{t} \mathrm{i} & =\text { Waktu pengamatan ke- } \mathrm{i}, \\
\mathrm{n} & =\text { Jumlah total pengamatan. }
\end{array}
$$

Formulasi dan konsentrasi biopestisida terhadap kolonisasi $B$. subtilis, $P$. fluorescens pada rizosfer, diskolorisasi floem, dan persentase penekanannya

Kolonisasi B. subtilis dan P. fluorescens pada akar atau tanah di sekitar rizosfer tanaman anyelir diamati sebelum aplikasi biopestisida dan pada saat panen (umur 120 HST) dengan mengadopsi metode Hsu et al. (1994). Akar tanaman sepanjang $2 \mathrm{~cm}$ atau $1 \mathrm{~g}$ tanah di sekitar rizosfer, dimasukkan ke dalam $9 \mathrm{ml}$ air steril, kemudian dilakukan pengenceran berseri dan pembiakan di atas media King's B selama 48 jam dalam inkubator pada suhu $30^{\circ} \mathrm{C}$. Setelah itu populasi B. subtilis dan $P$. fluorescens (tidak termasuk bakteri kontaminan) dihitung menggunakan colony counter Suntex Model CC-560, nomor seri: 930801828.

Serangan penyakit layu Fusarium pada anyelir mengakibatkan jaringan floem berwarna coklat atau diskolorisasi floem. Diskolorisasi floem diamati pada saat panen dengan cara memotong batang, yang dimulai dari leher akar sampai titik tumbuh, kemudian batang tersebut dibelah melintang lalu diamati perubahan warna coklat pada floem. Diskolorisasi floem dihitung berdasarkan rumus:

$$
\mathrm{a} / \mathrm{n} \times 100 \%
$$

di mana:

$\mathrm{a}=$ Panjang bagian floem yang bergejala kecoklatan,

$\mathrm{n}=$ Panjang batang bagian floem dari leher akar sampai titik tumbuh.

Selain parameter pengamatan tersebut dihitung juga persentase penekanan intensitas penyakit dibandingkan dengan perlakuan kontrol. Persentase penekanan sebagai bahan pertimbangan kriteria efikasi dihitung berdasarkan rumus:

$$
\mathrm{PP}=(\mathrm{K}-\mathrm{T} / \mathrm{K}) \times 100 \%
$$

di mana:

$\mathrm{PP}=$ Persentase penekanan,

$\mathrm{K}=$ Kontrol,

$\mathrm{T}=$ Perlakuan.

\section{HASIL DAN PEMBAHASAN}

\section{Uji Viabilitas Bahan Aktif dalam Bahan Pembawa Biopestisida}

Pengamatan terhadap viabilitas bahan aktif biopestisida dalam bahan pembawa dan pengukuran $\mathrm{pH}$ media dilaksanakan sebanyak tiga kali menggunakan $\mathrm{pH}$ meter digital EUTECH nomor seri : 280297, yaitu sebelum fermentasi, 1 , dan 2 bulan setelah fermentasi berakhir. Bakteri berkembang dengan baik pada $\mathrm{pH}$ normal atau sedikit basa. Dalam penelitian ini $\mathrm{pH}$ media setelah dicampur dengan dua spesies bakteri antagonis (sebelum difermentasi) menunjukkan pH 6,7 menjadi 3,4 setelah difermentasi selama 3 minggu. Hal tersebut diduga disebabkan oleh bakteri antagonis pada masa pertumbuhan dan perkembangannya mensekresikan suatu metabolit yang menyebabkan penurunan $\mathrm{pH}$ media dari netral $(6,7)$ menjadi $\mathrm{pH}$ asam $(\mathrm{pH} 3,4)$. Hasil penghitungan populasi agens biokontrol dan $\mathrm{pH}$ dalam formulasi disajikan dalam Tabel 3.

Pada Tabel 3 diketahui bahwa populasi bahan aktif (bakteri antagonis) setelah dilakukan proses fermentasi selama 3 minggu, meningkat dibandingkan sebelum fermentasi. Populasi awal bakteri antagonis sebelum fermentasi rerata $10^{7}-10^{9}$ menjadi $10^{10}-10^{12} \mathrm{cfu} / \mathrm{ml}$ pada 3 minggu setelah fermentasi. Populasi kedua agens biokontrol tersebut setelah 2 bulan disimpan cenderung stabil yaitu $10^{10}-10^{11} \mathrm{cfu} /$ $\mathrm{ml}$. Hal ini menandakan bahwa bahan pembawa berupa hasil fermentasi bahan organik berupa ekstrak kascing dan molase tidak berpengaruh terhadap bakteri antagonis dari spesies $B$. subtilis dan $P$. fluorescens. Selain itu, $\mathrm{pH}$ media juga tidak berpengaruh terhadap dinamika populasi bakteri tersebut. Hal ini mengindikasikan bahwa antara bahan aktif dan bahan pembawa bersifat kompatibel pada kondisi pH 3,4 atau 6,7. 
Tabel 3. Dinamika populasi agens biokontrol dalam berbagai formulasi biopestisida pada 0, 1, dan 2 bulan setelah fermentasi (Population dynamics of biocontrol agents on biopesticide formulations at 0,1 , and 2 months after fermentation)

\begin{tabular}{|c|c|c|c|c|c|c|}
\hline \multirow{2}{*}{$\begin{array}{c}\text { Jenis formulasi biopestisida } \\
\text { sebelum difermentasi (Type of } \\
\text { biopesticide formulations before } \\
\text { fermentation) }\end{array}$} & \multicolumn{6}{|c|}{$\begin{array}{c}\text { Dinamika populasi bakteri antagonis pada ... bulan setelah fermentasi } \\
\text { (Population dynamics of bacterial antagonists at ... month before fermentations), cfu/ml }\end{array}$} \\
\hline & \multicolumn{2}{|c|}{$\mathbf{0}$} & \multicolumn{2}{|c|}{1} & \multicolumn{2}{|c|}{2} \\
\hline \multicolumn{7}{|l|}{ PH 6,7: } \\
\hline $10 \% \mathrm{Kas}+10 \% \mathrm{Mol}$ & B: - & P: - & B: - & P: - & B: - & P: - \\
\hline $10 \% \mathrm{Pkd}+10 \% \mathrm{Mol}$ & B: - & P: - & B: - & P: - & B: - & P: - \\
\hline $10 \% \mathrm{Kas}+10 \% \mathrm{Mol}+\mathrm{BP}$ & $\mathrm{B}:(7 \pm 3) 10^{9}$ & $\mathrm{P}:(4 \pm 1) 10^{9}$ & $\mathrm{~B}:(9 \pm 3) 10^{8}$ & $\mathrm{P}:(2 \pm 1) 10^{10}$ & $\mathrm{~B}:(8 \pm 3) 10^{7}$ & $\mathrm{P}:(3 \pm 2) 10^{9}$ \\
\hline $10 \% \mathrm{Pkd}+10 \% \mathrm{Mol}+\mathrm{BP}$ & $\mathrm{B}:(3 \pm 1) 10^{7}$ & $\mathrm{P}:(9 \pm 5) 10^{9}$ & $\mathrm{~B}:(6 \pm 2) 10^{7}$ & $\mathrm{P}:(7 \pm 2) 10^{10}$ & $\mathrm{~B}:(7 \pm 5) 10^{7}$ & $\mathrm{P}:(6 \pm 3) 10^{8}$ \\
\hline \multicolumn{7}{|l|}{ PH 3,4: } \\
\hline $10 \% \mathrm{Kas}+10 \% \mathrm{Mol}$ & B: - & P: - & B: - & P: - & B: - & P: - \\
\hline $10 \% \mathrm{Pkd}+10 \% \mathrm{Mol}$ & B: - & P: - & B: - & P: - & B: - & P: - \\
\hline $10 \% \mathrm{Kas}+10 \% \mathrm{Mol}+\mathrm{BP}$ & $\mathrm{B}:(9 \pm 5) 10^{12}$ & $\mathrm{P}:(7 \pm 2) 10^{12}$ & $\mathrm{~B}:(7 \pm 3) 10^{12}$ & $\mathrm{P}:(7 \pm 3) 10^{12}$ & $\mathrm{~B}:(9 \pm 6) 10^{11}$ & $\mathrm{P}:(7 \pm 4) 10^{11}$ \\
\hline $10 \% \mathrm{Pkd}+10 \% \mathrm{Mol}+\mathrm{BP}$ & $\mathrm{B}:(9 \pm 5) 10^{10}$ & $\mathrm{P}:(9 \pm 4) 10^{11}$ & $B:(7+2) 10^{10}$ & $P:(7 \pm 5) 10^{11}$ & $\mathrm{~B}:(6 \pm 5) 10^{10}$ & $\mathrm{P}:(9 \pm 5) 10^{10}$ \\
\hline
\end{tabular}

Pembuatan formulasi biopestisida ini menggunakan molase dan ekstrak kascing. Molase dapat berperan sebagai bahan pembawa, pelindung dari sinar matahari, dan sebagai sumber nutrisi. Kandungan utama molase ialah senyawa gula terutama sukrose (Burges dan Jones 1998). Bahan lain yang dapat digunakan sebagai sumber makanan bagi agens biokontrol selain molase, ialah tepung gandum dan jagung, dedak gandum, kecambah gandum, tepung kedelai, dan gluten jagung (Paau 1998).

Selanjutnya Burges dan Jones (1998) menyebutkan bahwa molase merupakan salah satu bahan aditif yang paling bermanfaat dan salah satu dari sedikit bahan yang hampir selalu memberikan manfaat positif baik di laboratorium maupun di lapangan. Hal ini kemungkinan disebabkan oleh sifatnya yang multifungsi, yaitu sebagai pelindung matahari, pengental, fagostimulant, dan sebagai penutup faktor perlawanan dari daun. Selain itu molase juga dapat berperan sebagai pengawet (preservatif) selama penyimpanan.

Kascing ialah kotoran cacing yang berperan sebagai pupuk organik hasil sekresi cacing Lumbricus rubellus. Sebagian besar bahan organik yang dicerna oleh cacing tersebut dikembalikan ke dalam tanah dalam bentuk nutrisi yang mudah dimanfaatkan oleh tanaman dan mikrobe. Kascing merupakan bahan yang telah terseleksi dan mengalami pengayaan selama proses dalam usus cacing tanah, sehingga memiliki keunggulan tersendiri dibanding dengan bahan aslinya (Nusantara et al. 2007).

Formulasi dan Konsentrasi Biopestisida Organik terhadap Waktu Inkubasi, Intensitas Serangan Layu Fusarium, AUDPC, Diskolorisasi Floem, dan Persentase Penekanannya

Formulasi biopestisida terhadap waktu inkubasi dan intensitas serangan $F$. oxysporum f. sp. dianthi pada anyelir

Serangan $F$. oxysporum f. sp. dianthi pada tanaman anyelir menunjukkan gejala luar berupa layu pada sejumlah daun. Hal ini diduga karena terganggunya jaringan xilem ke seluruh bagian tanaman sebagai akibat terjadinya kerusakan jaringan tersebut (Djatnika et al. 2003). Menurut Davis (1969) kelayuan tanaman yang terinfeksi Fusarium disebabkan oleh toksin asam fusarat yang diekskresikan oleh patogen tersebut selama proses infeksi. Toksin ini dapat menghambat fungsi mitokondria, dan menekan enzim katalase, serta mengganggu membran sel yang dapat mengakibatkan kebocoran ion.

Pada Tabel 4 tampak bahwa intensitas serangan F. oxysporum. f. sp. dianthi pada tanaman anyelir bervariasi bergantung pada kemangkusan masing-masing perlakuan. Intensitas serangan 
Tabel 4. Waktu inkubasi, intensitas serangan layu Fusarium, dan persentase penekan pada anyelir yang mendapat perlakuan beberapa formulasi biopestisida yang berbeda (Incubation times, disease intensity, and its suppresing on carnation which have had different biopesticide formulation)

\begin{tabular}{|c|c|c|c|c|c|c|c|c|}
\hline \multirow{2}{*}{$\begin{array}{c}\text { Perlakuan } \\
\text { (Treatments) }\end{array}$} & \multirow{2}{*}{$\begin{array}{c}\text { W I } \\
\text { (Hari) }\end{array}$} & \multicolumn{5}{|c|}{$\begin{array}{c}\text { Intensitas serangan Fusarium pada hari } \\
\text { ke ... setelah tanam (Disease intensity of } \\
\text { Fusarium at ... after planting), } \%\end{array}$} & \multicolumn{2}{|c|}{$\begin{array}{c}\text { Penekanan } \\
\text { dibanding (Sup- } \\
\text { presing), \% } \\
\end{array}$} \\
\hline & & 36 & 50 & 64 & 78 & 92 & $\begin{array}{c}\text { Kon- } \\
\text { trol }\end{array}$ & $\begin{array}{c}\text { Da- } \\
\text { zomet } \\
0,2 \%\end{array}$ \\
\hline $10 \%$ Kas $+10 \% \mathrm{Mol}+\mathrm{BP}$, kons $0,1 \%$ & 7 & $5,00 \mathrm{a}^{*}$ & $10,00 \mathrm{a}$ & $10,00 \mathrm{a}$ & $11,67 \mathrm{~b}$ & $11,67 \mathrm{~b}$ & 61,10 & - \\
\hline $10 \%$ Kas $+10 \% \mathrm{Mol}+\mathrm{BP}$, kons $0,3 \%$ & 7 & $6,67 \mathrm{a}$ & $8,33 \mathrm{a}$ & $11,67 \mathrm{a}$ & $15,00 \mathrm{~b}$ & $16,67 \mathrm{~b}$ & 44,43 & - \\
\hline $10 \% \mathrm{Kas}+10 \% \mathrm{Mol}+\mathrm{BP}$, kons $0,5 \%$ & 35 & & $1,67 \mathrm{a}$ & $1,67 \mathrm{a}$ & $1,67 \mathrm{c}$ & $1,67 \mathrm{c}$ & 94,43 & 85,69 \\
\hline $10 \% \mathrm{Kas}+10 \% \mathrm{Mol}+\mathrm{BP}$, kons $0,7 \%$ & 7 & $1,67 \mathrm{a}$ & $1,67 \mathrm{a}$ & $1,67 \mathrm{a}$ & $1,67 \mathrm{c}$ & $1,67 \mathrm{c}$ & 94,43 & 85,69 \\
\hline $10 \% \mathrm{Pkd}+10 \% \mathrm{Mol}+\mathrm{BP}$, kons $0,1 \%$ & 35 & $0 \quad \mathrm{a}$ & $3,33 \mathrm{a}$ & $5,00 \mathrm{a}$ & $5,00 \mathrm{c}$ & $8,33 \mathrm{bc}$ & 72,23 & 28,62 \\
\hline $10 \% \mathrm{Pkd}+10 \% \mathrm{Mol}+\mathrm{BP}$, kons $0,3 \%$ & 7 & $1,67 \mathrm{a}$ & $1,67 \mathrm{a}$ & $3,33 \mathrm{a}$ & $5,00 \mathrm{c}$ & $5,00 \mathrm{c}$ & 83,33 & 57,16 \\
\hline $10 \% \mathrm{Kkd}+10 \% \mathrm{Mol}+\mathrm{BP}$, kons $0,5 \%$ & 7 & $1,67 \mathrm{a}$ & $1,67 \mathrm{a}$ & $1,67 \mathrm{a}$ & $3,33 \mathrm{c}$ & $3,33 \mathrm{c}$ & 88,90 & 71,47 \\
\hline $10 \% \mathrm{Kkd}+10 \% \mathrm{Mol}+\mathrm{BP}$, kons $0,7 \%$ & 7 & 3,33 a & $3,33 \mathrm{a}$ & $3,33 \mathrm{a}$ & $3,33 \mathrm{c}$ & $3,33 \mathrm{c}$ & 88,90 & 71,47 \\
\hline Dazomet $0,2 \%$ & 7 & $3,33 \mathrm{a}$ & $5,00 \mathrm{a}$ & $10,00 \mathrm{a}$ & $10,00 \mathrm{~b}$ & $11,67 \mathrm{~b}$ & 61,10 & - \\
\hline Kontrol (Air ledeng) & 7 & $26,67 \mathrm{~b}$ & $28,33 \mathrm{~b}$ & $28,33 \mathrm{~b}$ & $28,33 \mathrm{a}$ & $30,00 \mathrm{a}$ & - & - \\
\hline $\mathrm{KK}(\mathrm{CV}), \%$ & & 15,07 & 17,25 & 15,75 & 18,95 & 15,75 & & \\
\hline
\end{tabular}

* Angka rerata yang diikuti huruf yang sama menunjukkan tidak berbeda nyata menurut Uji Jarak Berganda Duncan pada taraf nyata 5\% (Mean followed by the same letters are not significantly different at 5\% level according to Duncan Multiple Range Test)

tersebut bergeser antara 0 dan 30\%, dengan waktu inkubasi berkisar antara 7 dan 35 HST. Perlakuan B. subtilis dan P. fluorescens (BaPf) yang disuspensikan masing-masing dengan kascing + molase pada taraf konsentrasi $0,5 \%$, dan pupuk kandang kotoran kuda + molase taraf konsentrasi $0,1 \%$, menunjukkan waktu inkubasi yang paling lama, yaitu 35 hari. Waktu inkubasi terlama kedua ditunjukkan oleh perlakuan lainnya termasuk perlakuan kontrol dan dazomet, yaitu 7 hari.

Pada umur 36-64 HST pengaruh perlakuan BaPf yang disuspensikan ke dalam ekstrak kascing + molase pada konsentrasi 0,5 dan $0,7 \%$ dan pupuk kandang kotoran kuda + molase pada konsentrasi $0,5 \%$, secara nyata lebih efektif dibandingkan dengan perlakuan lainnya. Hal ini ditunjukkan oleh rendahnya intensitas serangan pada perlakuan tersebut, berkisar antara $0-1,67 \%$.

Pada umur 78-92 HST, perlakuan BaPf yang disuspensikan dengan kascing + molase pada konsentrasi 0,5 dan $0,7 \%$ masing-masing menunjukkan intensitas serangan yang paling rendah, yaitu $1,67 \%$ dengan persentase penekanan penyakit dibanding perlakuan kontrol dan dazomet masing-masing sebesar 94,43, 85, dan
$69 \%$. Hal ini berarti bahwa kemangkusan kedua perlakuan tersebut lebih stabil bila dibanding dengan perlakuan lainnya.

Dari lima kali pengamatan dapat dilihat bahwa perlakuan BaPf yang disuspensikan ke dalam ekstrak kascing + molase, kemudian difermentasikan dalam biofermentor selama 3 minggu dapat menekan serangan $F$. oxysporum f. sp. dianthi pada anyelir. Hal ini disebabkan antibiotik atau toksin yang diproduksi oleh kedua mikrobe antagonis (B. subtilis dan $P$. fluorescens). Sejalan dengan pendapat tersebut, Hartman et al. (1993), Leisinger dan Margraff (1979) melaporkan bahwa bakteri Pseudomonas merupakan kelompok terbesar bakteri yang memproduksi antibiotik yang digunakan sebagai agens pengendali hayati patogen pada beberapa patogen tanaman. Misalnya $P$. fluorescens dapat mengendalikan $P$. syringae pv. phaseolicola pada buncis (Teliz dan Burkholder 1960) dan Gaeumannomycetes tritici pada gandum (Thomashow danWeller 1988), Ralstonia solanacearum pada tomat (Mulya 1997), dan Plasmodiophora brassicae pada caisin (Hanudin dan Marwoto 2003). Pseudomonas fluorescens dapat menurunkan pertumbuhan penyakit busuk pangkal batang yang disebabkan oleh Pythium spp. (Gurusidaiah et al. 1986). 


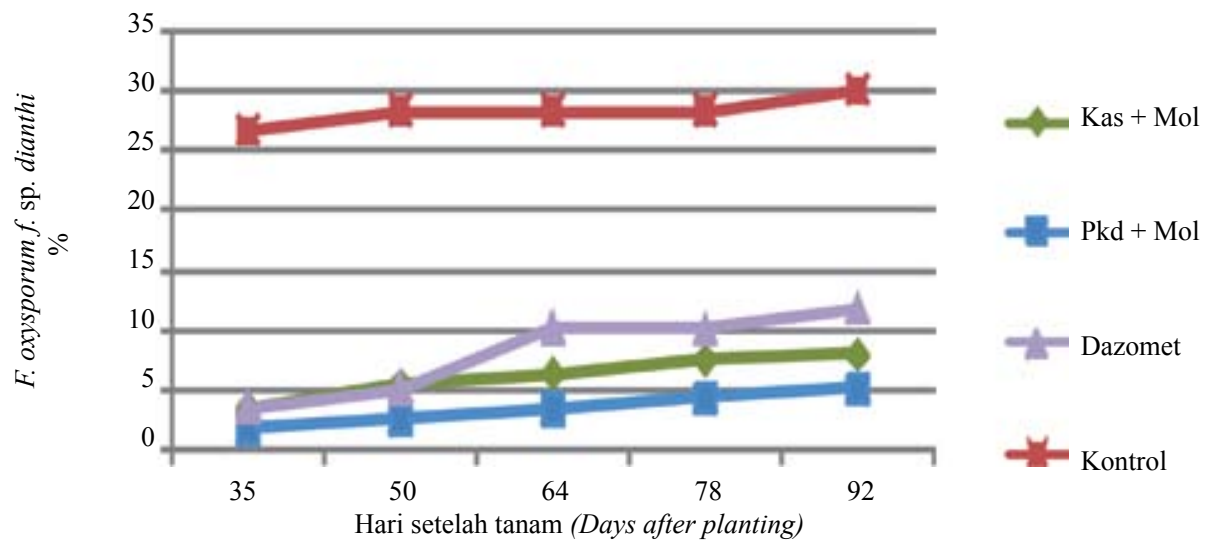

Gambar 1. Perkembangan intensitas serangan $F$. oxysporum f. sp. dianthi dengan perlakuan ekstrak kascing, pupuk kandang ditambah isolat B. subtilis dan P. fluorescens, dazomet, dan kontrol (Development of F. oxysporum $f . s p$. dianthi disease intensity with vermi compost extract, horse manure by added with $B$. subtilis and $P$. fluorescens isolates, dazomet, and control)

Bacillus subtilis dilaporkan dapat menekan serangan $F$. oxysporum f. sp. dianthi pada tanaman anyelir sampai dengan $40 \%$ (Yuen et al. 1985), penyakit karat pada buncis (Baker et al. 1985), penyakit layu Verticillium pada maple (Hall et al. 1986, Hall dan Davis 1990), dan penyakit busuk coklat yang disebabkan oleh Monilinia fructicola Wint. pada tanaman peach (Pusey et al. 1986). Sementara B. subtilis isolat krisan dapat menekan serangan damping off yang disebabkan oleh Rhizoctonia solani (Hanudin et al. 2004a), sedang gabungan antara B. subtilis dan $P$. fluorescens efektif dapat mengendalikan penyakit layu Fusarium pada anyelir sebesar 63,63\% (Hanudin et al. 2004b).
Penelitian terhadap tanah-tanah bera bekas tambang di Ohio, Amerika Serikat menunjukkan bahwa penggunaan kascing dapat meningkatkan kadar $\mathrm{P}$ dan $\mathrm{K}$ tersedia bagi tanaman masingmasing sebesar 16,5 dan 19\% (Khairuman dan Amri 2009). Selain itu, kascing mengandung hormon auksin, sitokinin, dan giberelin, serta memiliki kapasitas tukar kation, mampu menyimpan air, dan mengandung populasi jasad hidup yang tinggi (Aira et al. 2006). Dengan adanya unsur-unsur tersebut, tanaman menjadi sehat sehingga dapat menangkal serangan dari organisme pengganggu tumbuhan (OPT) termasuk di dalamnya $F$. oxysporum f. sp. dianthi pada anyelir. Serangan $F$. oxysporum f. sp. dianthi

Tabel 5. Luas areal di bawah kurva perkembangan penyakit $F$. oxysporum $\mathrm{f}$. sp. dianthi pada 10 perlakuan jenis komposisi dan konsentrasi biopestisida (Area under diseases progress curve of $F$. oxysporum f.sp. dianthi for the mean of 10 composition and concentration of biopesticides formulations)

\begin{tabular}{|c|c|}
\hline Jenis formulasi (Kind of formulations) & AUDPC \\
\hline $10 \% \mathrm{Kas}+10 \% \mathrm{Mol}+\mathrm{BP}$, kons $0,1 \%$ & $560,07 \mathrm{c}$ \\
\hline $10 \%$ Kas $+10 \% \mathrm{Mol}+\mathrm{BP}$, kons $0,3 \%$ & $618,38 \mathrm{c}$ \\
\hline $10 \% \mathrm{Kas}+10 \% \mathrm{Mol}+\mathrm{BP}$, kons $0,5 \%$ & 81,83 a \\
\hline $10 \% \mathrm{Kas}+10 \% \mathrm{Mol}+\mathrm{BP}$, kons $0,7 \%$ & 93,52 a \\
\hline $10 \% \mathrm{Pkd}+10 \% \mathrm{Mol}+\mathrm{BP}$, kons $0,1 \%$ & $244,93 \mathrm{~b}$ \\
\hline $10 \% \mathrm{Pkd}+10 \% \mathrm{Mol}+\mathrm{BP}$, kons $0,3 \%$ & $186,69 \mathrm{~b}$ \\
\hline $10 \% \mathrm{Kkd}+10 \% \mathrm{Mol}+\mathrm{BP}$, kons $0,5 \%$ & $128,38 \mathrm{ab}$ \\
\hline $10 \% \mathrm{Kkd}+10 \% \mathrm{Mol}+\mathrm{BP}$, kons $0,7 \%$ & 186,4 \\
\hline Dazomet $0,2 \%$ & 455,0 \\
\hline Kontrol (Air ledeng) & $1.586,55$ \\
\hline $\mathrm{KK}(\mathrm{CV}), \%$ & 17,69 \\
\hline & 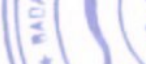 \\
\hline
\end{tabular}


pada tanaman yang mendapat perlakuan tersebut cenderung lebih rendah bila dibandingkan dengan perlakuan lainnya.

Luas areal di bawah kurva perkembangan penyakit $F$. oxysporum f. sp. dianthi

Pada percobaan ini perlakuan yang menunjukkan slope yang paling rendah, tidak selalu menunjukkan angka AUDPC yang paling rendah pula. Perlakuan ekstrak pupuk kandang kotoran kuda ditambah dengan molase dan isolat $B$. subtilis, dan $P$. fluorescens menunjukkan slope paling rendah (Gambar 1). Namun nilai AUDPC yang terendah $(81,83)$ ditunjukkan oleh perlakuan ekstrak kascing yang ditambah dengan molase dan isolat $B$. subtilis, P. fluorescens, pada taraf konsentrasi 0,5\%. AUDPC terendah kedua ditunjukkan oleh perlakuan ekstrak kascing ditambah dengan molase, isolat B. subtilis, dan $P$. fluorescens pada taraf konsentrasi $0,7 \%$ dengan AUDPC ialah 93,52 (Tabel 5).

Formulasi dan konsentrasi biopestisida terhadap kolonisasi bakteri antagonis, diskolorisasi floem, dan persentase penekanannya

Kemangkusan formulasi biopestisida organik berbahan aktif $P$. fluorescens terhadap intensitas serangan $F$. oxysporum f. sp dianthi pada tanaman anyelir tampaknya dipengaruhi oleh derajat kolonisasi (DK) bakteri antagonis pada rizosfer anyelir. Pada Tabel 6 tampak bahwa perlakuan ekstrak kascing atau pupuk kandang kuda + molase keduanya pada taraf konsentrasi $0,7 \%$ menunjukkan DK pada saat panen yang paling tinggi (B. subtilis: $6 \times 10^{4}$, P. fluorescens: $7 \times 10^{6}$ $\mathrm{cfu} / \mathrm{mg}$ akar untuk ekstrak kascing dan B. subtilis: $7 \times 10^{4}$, P. fluorescens: $5 \times 10^{6} \mathrm{cfu} / \mathrm{mg}$ akar untuk ekstrak pupuk kandang kuda).

Mekanisme kolonisasi terjadi karena asam amino, asam organik, vitamin, alkaloid, substansi fenolat, serta unsur anorganik seperti kalium, kalsium, magnesium, dan mangan dalam tanaman dimanfaatkan untuk pertumbuhan dan perkembangannya, sehingga kesempatan propagul patogen memanfaatkan senyawa tersebut menjadi berkurang (Tukey 1979 dalam Cook dan Baker 1983). Sejalan dengan pendapat tersebut Hsu et al. (1994) melaporkan bahwa P. fuorescens dapat mengkolonisasi rizosfer tomat dan menekan serangan $R$. solanacearum hingga $50 \%$. Namun hal tersebut tidak berlaku bagi perlakuan ekstrak kascing + molase pada taraf konsentrasi $0,5 \%$.

Tabel 6. Kolonisasi $B$. subtilis dan $P$. fluorescens pada rizosfer anyelir sebelum perlakuan dan pada saat panen, diskolorisasi floem, dan persentase penekanannya umur 120 HST (B. subtilis and P. fluorescens colonization at carnation rhizosphere, phloem discoloration, and its suppression at $120 \mathrm{DAT}$ )

\begin{tabular}{|c|c|c|c|c|c|c|}
\hline \multirow{3}{*}{\begin{tabular}{l}
\multicolumn{1}{c}{$\begin{array}{c}\text { Perlakuan } \\
\text { (Treatments) }\end{array}$} \\
$10 \% \mathrm{Kas}+10 \% \mathrm{Mol}+\mathrm{BP}$, \\
kons $0,1 \%$
\end{tabular}} & \multicolumn{4}{|c|}{$\begin{array}{l}\text { Populasi } B . \text { subtilis dan } P \text {. fluorescens pada rizosfer } \\
\text { anyelir (cfu/mg akar) (Population of } B \text {. subtilis and } P \text {. } \\
\text { fluorescens on carnation rhizosphere), cfu/mg roots }\end{array}$} & \multirow{3}{*}{$\begin{array}{c}\begin{array}{c}\text { Diskolori- } \\
\text { sasi floem }\end{array} \\
\begin{array}{c}\text { (Phloem dis- } \\
\text { colorations) } \\
\text { \% }\end{array} \\
38,61\end{array}$} & \multirow{3}{*}{$\begin{array}{c}\begin{array}{c}\text { Penekanan } \\
\text { (Suppres- } \\
\text { sion) } \\
\%\end{array} \\
\mathrm{Ns}\end{array}$} \\
\hline & \multicolumn{2}{|c|}{$\begin{array}{c}\text { Sebelum perlakuan } \\
\text { (Before treatment) }\end{array}$} & \multicolumn{2}{|c|}{$\begin{array}{c}\text { Saat panen } \\
\text { (Harvest times) }\end{array}$} & & \\
\hline & B: - & $\mathrm{P}:(3 \pm 2) 10^{2}$ & $\mathrm{~B}:(5 \pm 2) 10^{3}$ & $\mathrm{P}:(7 \pm 3) 10^{3}$ & & \\
\hline $\begin{array}{l}10 \% \mathrm{Kas}+10 \% \mathrm{Mol}+\mathrm{BP} \\
\text { kons } 0,3 \%\end{array}$ & $\mathrm{~B}:(2 \pm 1) 10^{2}$ & $\mathrm{P}:(5 \pm 2) 10^{2}$ & $\mathrm{~B}:(5 \pm 2) 10^{3}$ & $P:(6 \pm 3) 10^{4}$ & 21,66 & 16,44 \\
\hline $\begin{array}{l}10 \% \mathrm{Kas}+10 \% \mathrm{Mol}+\mathrm{BP} \text {, } \\
\text { kons } 0,5 \%\end{array}$ & $\mathrm{~B}:(7 \pm 2) 10^{2}$ & $\mathrm{P}:(5 \pm 3) 10^{2}$ & $\mathrm{~B}:(9 \pm 5) 10^{3}$ & $\mathrm{P}:(2 \pm 1) 10^{5}$ & 19,08 & 26,39 \\
\hline $\begin{array}{l}10 \% \mathrm{Kas}+10 \% \mathrm{Mol}+\mathrm{BP} \\
\text { kons } 0,7 \%\end{array}$ & $\mathrm{~B}:(3 \pm 2) 10$ & $\mathrm{P}:(5 \pm 2) 10^{2}$ & $\mathrm{~B}:(6 \pm 3) 10^{4}$ & $\mathrm{P}:(7 \pm 2) 10^{6}$ & 17,70 & 31,71 \\
\hline $\begin{array}{l}10 \% \mathrm{Pkd}+10 \% \mathrm{Mol}+\mathrm{BP} \\
\text { kons } 0,1 \%\end{array}$ & $\mathrm{~B}:(7 \pm 2) 10^{2}$ & $\mathrm{P}:(5 \pm 3) 10^{2}$ & $\mathrm{~B}:(8 \pm 3) 10^{3}$ & $\mathrm{P}:(7 \pm 5) 10^{3}$ & 26,31 & Ns \\
\hline $\begin{array}{l}10 \% \mathrm{Pkd}+10 \% \mathrm{Mol}+\mathrm{BP} \\
\text { kons } 0,3 \%\end{array}$ & $\mathrm{~B}:(9 \pm 7) 10^{2}$ & $\mathrm{P}:(5 \pm 2) 10^{2}$ & $\mathrm{~B}:(7 \pm 4) 10^{4}$ & $\mathrm{P}:(9 \pm 5) 10^{4}$ & 22,97 & 11,38 \\
\hline $\begin{array}{l}10 \% \text { Kkd }+10 \% \mathrm{Mol}+ \\
\text { BP, kons } 0,5 \%\end{array}$ & $\mathrm{~B}:(3 \pm 2) 10$ & $P:(5 \pm 2) 10^{2}$ & $\mathrm{~B}:(2 \pm 1) 10^{3}$ & $\mathrm{P}:(5 \pm 2) 10^{5}$ & 20,85 & 19,56 \\
\hline $\begin{array}{l}10 \% \mathrm{Kkd}+10 \% \mathrm{Mol}+ \\
\mathrm{BP}, \text { kons } 0,7 \%\end{array}$ & $\mathrm{~B}:(2 \pm 1) 10$ & $\mathrm{P}:(5 \pm 2) 10^{2}$ & $\mathrm{~B}:(7 \pm 3) 10^{4}$ & $P:(5 \pm 3) 10^{6}$ & 18,87 & \\
\hline Dazomet $0,2 \%$ & $\mathrm{~B}:(2 \pm 1) 10$ & $\mathrm{P}(5 \pm 2) 10^{2}$ & $\mathrm{~B}:(2 \pm 1) 10$ & $\mathrm{P}:(3 \pm 2) 10^{2}$ & 24,81 & \\
\hline Kontrol (Air ledeng) & $\mathrm{B}:(2 \pm 1) 10$ & $P:(4 \pm 2) 10$ & $\mathrm{~B}:(2 \pm 1) 10^{2}$ & $\mathrm{P}:(3 \pm 2) 10^{2}$ & 25,92 & \\
\hline
\end{tabular}

$\mathrm{Ns}=$ Tidak dapat menekan diskolorisasi floem (No suppressing phloem discolorations) 
Derajat kolonisasi pada saat panen perlakuan ini rendah bila dibandingkan dengan kedua perlakuan tersebut di atas (B. subtilis: $9 \times 10^{3}$ dan P. fluorescens: $2 \times 10^{5} \mathrm{cfu} / \mathrm{mg}$ akar), tetapi menunjukkan angka AUDPC dan efisiensi yang paling rendah (81,83). Sumardiyono et al. (2001) melaporkan bahwa P. fluorescens dapat menekan serangan patogen dengan cara mengimbas gen ketahanan, dengan membentuk senyawa fitoaleksin yang komposisinya terdiri atas asam salisilat. Hal ini sesuai dengan pendapat Kosack dan Jones (1996) yang menyatakan bahwa asam salisilat memberikan sinyal penting dalam mekanisme ketahanan dan menghambat mikroorganisme dalam tubuh tanaman. Diduga adanya akumulasi sinyal asam salisilat terjadi lignifikasi dalam jaringan tanaman anyelir, sehingga tanaman lebih tahan terhadap serangan penyakit layu Fusarium.

Fusarium dapat menghasilkan enzim pektinmetilesterase, poligalakturonase, dan enzim penghancur lainnya. Enzim-enzim tersebut menyebabkan kerusakan pada dinding sel, sehingga terlihat diskolorisasi pada jaringan yang terinfeksi dan gangguan pertumbuhan, yang mengakibatkan tanaman mati (Waggoner dan Dimond 1985). Perlakuan ekstrak kascing + molase pada taraf konsentrasi 0,7 dan $0,5 \%$ masing-masing menunjukkan diskolorisasi floem terendah pertama dan kedua (17,70 dan 19,08\%), dengan persentase penekanan masing-masing sebesar 31,71 dan 26,39\%.

Apabila dihubungkan antara Tabel 4, 5, dan 6, maka perlakuan ekstrak kascing + molase yang ditambah dengan isolat $B$. subtilis dan $P$. fluorescens pada taraf konsentrasi $0,5 \%$ cenderung konsisten dapat menekan $F$. oxysporum f. sp dianthi pada anyelir sebanyak $26,39 \%$.

\section{KESIMPULAN}

1. Viabilitas B. subtilis, dan P. fluorescens setelah dilakukan proses fermentasi selama 3 minggu, meningkat dibandingkan sebelum fermentasi. Populasi kedua agens biokontrol tersebut setelah 2 bulan disimpan cenderung stabil, populasinya berkisar antara $10^{10}-10^{11}$ $\mathrm{cfu} / \mathrm{ml}$.
2. Perlakuan ekstrak kascing + molase yang ditambah dengan isolat $B$. subtilis, dan $P$. fluorescens pada taraf konsentrasi $0,5 \%$ cenderung konsisten dapat menekan $F$. oxysporum f.sp dianthi pada anyelir.

\section{UCAPAN TERIMAKASIH}

Penulis mengucapkan terima kasih dan penghargaan yang setinggi-tingginya kepada Badan Penelitian dan Pengembangan Pertanian, melalui Puslitbang Hortikultura, dan Balai Penelitian Tanaman Hias yang telah membiayai, memberikan saran, kritik dalam perencanaan dan pelaksanaan penelitian. Penulis mengucapkan terima kasih juga kepada Sdr. Endang Sutarya, Dede Surachman, Muhidin, Dadang Kusnandar, Ade Sulaeman, Iskandar Sanusie, dan semua pihak yang telah membantu terlaksananya penelitian dan pelaporan ini.

\section{PUSTAKA}

1. Aira, M., F. Monroy, and J. Dominguez. 2006. Changes in Microbial Biomass and Microbial Activity of Pig Slurry after the Transit Through the Gut of the Earthworm Eudrilus eugeniae. Biol. Fertil Soil. 42:371-376.

2. Baker, C. J., R. J. Stavely, and N. Mock. 1985. Biocontrol of Bean Rust by Bacillus subtilis under Field Conditions. Plant. Dis. 69:770-772.

3. Burges, H.D. and K.A. Jones. 1998. Introduction. In Burges, H.D.(Ed.). Formulation of Microbial Biopesticides: Beneficial Microorganisms, Nemathodes, and Seed Treatments. Kluwer Academic Publisher, Dordrecht, Netherlands. 127 pp.

4. Cook, R. J. and K. F. Baker. 1983. The Nature and Practice of Biological Control of Plant Pathogens. The American Phytopathol. Soc. USA. 539 p.

5. Davis, D. 1969. Fusaric Acid in Selective Pathogenicity of Fusarium oxysporum. Phytopathol. 59:1391-1395.

6. Djatnika, I., I. Sukmayadi, dan Eliza. 2003. Seleksi Dini Ambon Hijau terhadap Layu Fusarium dengan Menggunakan Toksin Asam Fusarat. Dalam Suhardi, T., Suganda, dan A.S. Duriat (Eds.) Proseeding Kongres. Nasional PFI XVII, Bandung. Hlm. 181-184.

7. De Bach, P. A. 1974. Biological Control by Natural Enemies. Cambridge University Press. London. 157 pp.

8. Gurusidaiah, S., D. M. Weller, A. Sarkar, and R. J. Cook. 1986. Characterization of Antibiotic Produced by Strain of Pseudomonas fluorescens Inhibitory to Gaeumannomyces gramminis var. tritici and Pythium spp. Antimicrob. Agent and Chemoter. 29:488-495. 
9. Hanudin dan B. Marwoto. 2003. Pengendalian Penyakit Layu Bakteri dan Akar Gada pada Tomat dan Caisim Menggunakan Pseudomonas fluorescens. J. Hort. 13 (1):58-66.

10. , E. Silvia, B. Marwoto, Suhardi, dan W. Handayati. 2004a. Skrining Antagonistik Beberapa Strain Bacillus spp. terhadap Rhizoctonia solani Isolat Krisan. Agrin. 8(1):1-5.

11.

, B. Marwoto, A. Saefullah, K. Mulya, dan M. Machmud. 2004b. Formula Cair Pseudomonas fluorescens untuk Pengendalian Penyakit Layu Fusarium pada Anyelir. J. Hort. 14 (Eds. Khusus):403-409.

12. W. Nuryani, and K. Budiarto. 2008. Effectiveness of Bacillus subtilis and Pseudomonas fluorescens in Liquid Formulation to Control Important Diseases on Chrysanthemum and Chinese Cabbage. Agrivita. 30(3):255-262.

13.

B. Marwoto, B. Tjahjono, M. Machmud, dan K. Mulya. 2009. Komposisi Biopestisida Cair Berbahan Aktif Bacilllus subtilis dan Pseudomonas fluorescens untuk Pengendalian Penyakit Tanaman Hias dan Tanaman Lainnya. Sertifikat Paten No. I. D. 0022 384. Departemen Hukum dan Hak Asasi Manusia, Dirjen Haki. Jakarta, 12 Januari 2009. 19 Hlm.

14. Hall, T. J., Schreiber, R. L., and Leben, C. 1986. Effect of Xylem-Colonizing Bacillus spp. on Verticillium Wilt in Maples. Plant Dis. 70:521-524.

15. and W. E. E. Davis. 1990. Survival of Bacillus subtilis in Silver and Sugar Maple Seedlings Over a Two Year Period. Plant Dis. 74:608-609.

16. Hartman G. L., W. F. Hong, Hanudin, and A. C. Hayward. 1993. Potential of Biological and Chemical Control of Bacterial Wilt. In Hartman, G. L. and A.C. Hayward. (Eds.). Bacterial Wilt. Proceeding of an Interntional Conference. ACIAR Procc. 45:322-326.

17. Hsu, S. T., C. C. Chen, H. Y. Liu, and K. C. Tzeng. 1994. Colonization of Roots and Control of Bacterial Wilt of Tomato by Pseudomonas fluorescens. Hartman, G. L., and A. C. Hayward. (Eds.). Bacterial Wilt. Proceeding of an International Conference. ACIAR Procc. 45:305311 .

18. Isroi. 2005. Bioteknologi Mikrobe untuk Pertanian Organik. Lembaga Riset Perkebunan Indonesia. http:// www.agromeia.net. [27 Agustus 2010].

19. Jeger, M. J. and S. L. H. Viljanen-Rollinson. 2001. The Use of the Area Under Disease-Progress Curve (AUDPC) to Assess Quantitative Disease Resistance in Crop Cultivars. Theor Appl Genet. 102:32- 40.

20. Khairuman dan K. Amri. 2009. Mengeruk Untung dari Beternak Cacing. http://www.agromedia.net. [27 Agustus 2010].

21. Komada, H. 1975. Development of a Selective Medium for Quantitative Isolation of Fusarium oxysporum from Natural Soils. Rev. Plant. Prot. Res. 8:114-125.

22. Kosack, H. K. E. and J. D. Jones. 1996. Resistance Gene-Dependent Plant Defence Response. Plant Cell. 7(2):1773 -1786.

23. Leisinger, T. and R. Margraff. 1979. Secondary Metabolites of the Flourescens Pseudomonas. Microbiol. Rev. 43:422-442.
24. Loffler, H.J.M., and J.R. Mouris. 1989. Screening for Fusarium Resistance in Lily. Med. Fac. Landbouww. Rijksuniv. Gent. 54/2b:525-530.

25 . , and P. Rumine. 1991. Virulence and Vegetative Compatibility of Dutch and Italian Isolates Fusarium oxysporum f. sp. lilii. J. Phytophathol. 132:1220.

26. Manulis, S., A. Kogan, M. Reuven, and Y. B. Yephet. 1994. Use of RAPD Technique for Identification of Fusarium oxysporum f. sp. dianthi from Carnation. Phytophathol. 84: 98-101.

27. Maryam A. B. N. dan I Djatnika, 1994. Penelitian Pengendalian Hama dan Penyakit Penting pada Tanaman Anyelir Selama Pelita V. Pusat Penelitian dan Pengembangan Hortikultura. Hlm. 57-67.

28. Mulya, K. 1997. Penekanan Perkembangan Penyakit Layu Bakteri Tomat oleh Pseudomonas fluorescens. J. Hort. 7(2):685-691

29. Nusantara, A.D., I. Mansyur, C. Kusmana, L.K. Darusman, dan Soedarmadi. 2007. Peran Substrat Alami, Kadar Air, dan Sterilisasi dalam Produksi Spora Melalui Simbiosis Pueraria javanica dan Glomus etunicatum. J. Akta Agrosia. Edisi Khusus (2):204-212.

30. Paau, A. S. 1998. Formulation of Beneficial Organisms Applied to Soil. In Burges, H.D. (Ed.). Formulation of Microbial Biopesticides: Beneficial Microorganisms, Nemathodes, and Seed Treatments. Kluwer Academic Publishe, Dordrecht, Netherlands. p. 235-254.

31. Pusey, P.L., C.L. Wilson, M.W. Hotchkiss, and J.D. Franklin. 1986. Compatibiliy of Bacillus substilis for Postharvest Control of Peach Brown Rot with Commercial Fruit Waxes, Dicloran, and Cold-Storage Conditions. Plant Dis. 70:587-590.

32. Sumardiyono, C., S.M. Widyastuti, dan Y. Assi. 2001. Pengimbasan Ketahanan Pisang terhadap Penyakit Layu Fusarium dengan Pseudomonas fluorescens. Dalam Purwantara, A. (Ed.) Prosiding Kongres Nasional XVI dan Seminar Ilmiah Perhimpunan Fitopatologi Indonesia. Bogor, 22-24 Agutus 2001. Hlm. 257-259.

33. Suryana, A dan D. Cahyono. 2008. Teknologi Pembuatan Pupuk dan Biopestisida Organik. Diklat Peningkatan Kompetensi Pegawai dan Guru Bidang Keahlian Pertanian Organik. Departemen Bioteknologi dan Lingkungan. Departemen Pendidikan Nasional. 21 - 29 Juli 2008. 37 Hlm.

34. Straathof, T.P., Jansen, J., and H.J.M. Loffler. 1993. Determination of Resistance to Fusarium oxysporum in Lilium. Phytophathol. 83:568-572.

35. Teliz, O. M. and W. H. Brukholder. 1960. A Strain of Pseudomonas fluorescens Antagonistics to Pseudomonas phaseolicola and Other Bacterial Plant Pathogen. Phytophathol. 50:119-123.

36. Thomashow, L.S. and D.M. Weller. 1988. Role of Penazine Antibiotic from Pseudomonas fluorescens in Biological Control of Gaeumannomycetes graminis var. tritici. J. Bacteriol. 170:3499-3508.

37. Waggoner, P.E. and A.E. Dimond. 1985. Production and Role of Extracellular Dectic Enzymer of Fusarium oxysporum. Phytophathol. 45:79-87. 
Hanudin et al.: Biopestisida Organik Berbahan Aktif Bacillus subtilis dan Pseudomonas fluorescens...

38. Yephet. B. Y., M. Reuven, A. Zviebil, and D. Shinberg. 1996. Effect of Initial Inoculum and Cultivar Resistence on Incidence of Fusarium Wilt and Population Densities of Fusarium oxysporum f. sp. dianthi on Carnations and in Soil. Phytophathol. 86: 751-756.
39. Yuen, G. Y., M. N. Schroth, and McCain,A.H. 1985. Reduction of Fusarium Wilt of Carnation with Suppressive Soils and Antagonistic Bacteria. Plant Disease. 69:1071-1075.

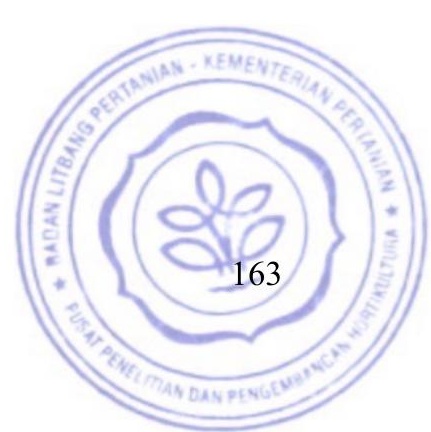

